\title{
Erratum to: Use of two validated in vitro tests to assess the embryotoxic potential of mycophenolic acid
}

\author{
Kathrin Eckardt • Ralf Stahlmann
}

Published online: 29 November 2009

(C) Springer-Verlag 2009

Erratum to: Arch Toxicol

DOI 10.1007/s00204-009-0476-1

Unfortunately there is a small mistake in Table 1:

"Concentration $(\mu \mathrm{g} /)$ " should read "Concentration $(\mu \mathrm{g} / \mathrm{l})$ ".

The online version of the original article can be found under doi:10.1007/s00204-009-0476-1.

K. Eckardt $\cdot$ R. Stahlmann $(\bowtie)$ Institute of Clinical Pharmacology and Toxicology,

Charité-Universitätsmedizin Berlin, Campus Benjamin Franklin,

Garystr. 5, 14195 Berlin, Germany

e-mail: ralf.stahlmann@ charite.de 